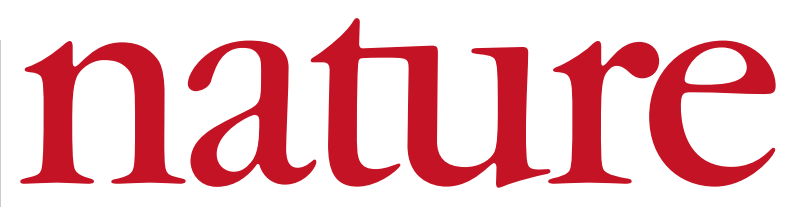

12 February 2004 Volume 427 Issue no 6975

\title{
Budget let-downs
}

With the United States facing tough economic times, science gets small change and less sense of direction from President Bush's research and development budget proposal for 2005.

$\mathrm{T}$ he generally lacklustre trajectory of the US research budget announced last week by President Bush hardly comes as a surprise, given the country's mountainous economic woes. The 2005 budget allows no growth, after inflation is taken into account, at the National Institutes of Health (NIH) or the National Science Foundation (NSF). Most other agencies do even less well, and those with any connection to environmental science, such as the Environmental Protection Agency and the National Oceanic and Atmospheric Administration, fare even worse.

Despite the protestations of biomedical-research lobbyists, the NIH was expected to enter a period of consolidation after five years of rapid growth. Congress may now look for direct results from an agency that now spends $\$ 28$ billion a year. But the treatment of the NSF, which funds most non-biomedical research at US universities, is disappointing and inconsistent. In late 2002, Bush signed an authorization bill that allowed for the doubling of the NSF's funding over five years. It was wrong for him to sign this bill, which was about long-term planning, and then ignore its contents.

The reorientation of NASA towards a revived human-spaceflight programme had already produced some scientific casualties ahead of the budget's release - most notably, a shortened life for the Hubble space telescope. But Hubble is only one of a number of odd choices made to redirect support towards a possible manned Moon mission. These should now be scrutinized in Congress.

Elsewhere, economic policy is coming home to roost. Despite a boost to combat mad cow disease, resources will remain short at the US Department of Agriculture and at the Centers for Disease Control and Prevention, which deals with global infectious diseases. With deficits as far as the eye can see, pressing scientific challenges facing the government evidently cannot attract sufficient resources.

The budget also shows few signs of effective interagency cooperation. The White House Office of Science and Technology Policy is supposed to orchestrate this, but its footprints on the budget are hard to see. To give just one example: NASA has set aside no funds for a space-based physics experiment that it planned in collaboration with the Department of Energy, the main US physics agency. But the energy department has budgeted to continue with it.

There is little indication in the research budget of direction from the centre. Previous presidents sought to coordinate action in areas such as climate change, nanotechnology and mathematics. Scientists don't always welcome these special initiatives, but in these areas they have been effective at getting things moving on US university campuses. No sign of that this year. If this turns out to be George W. Bush's last budget, he will have gone out with a whimper.

\section{Keys to capacity}

The task of advancing science in developing countries is beyond any one nation or organization. How can scientists help?

T wo reports just published have reached the same conclusion: developing countries need to grow their science and technology bases if they are to exploit new knowledge and technologies. This is not a luxury but an absolute necessity; otherwise the technology gap between them and industrialized countries will widen, and they will be impotent to roll back the plagues of killer diseases, or to generate sustainable agriculture, energy and water.

Inventing a Better Future (http://www.interacademycouncil.net) is by the InterAcademy Council, a body set up four years ago by 90 national science academies to advise the United Nations and other international bodies (see page 577). The second report, Science, Technology and Innovation (http://www.cid.harvard.edu/cidtech/ interim_report.doc) is by the science task force of the United Nations Millennium Project, a plan adopted by world leaders in 2000 that sets hopelessly unrealistic goals for slashing the burden of poverty, hunger and disease by 2015 , but has at least put them high on the agenda.

The reports' remedies largely rely on collective action by individual governments and the international community. This is essential, but bureaucracy and inertia will mean that we shouldn't expect progress anytime soon. Meanwhile, the international scientific community could do more to help expedite the same goals.

The Bill and Melinda Gates Foundation, the UK Wellcome Trust and other charities already generously support centres in the developing world. And the Howard Hughes Medical Institute, the
National Institutes of Health's Fogarty International Center, and many research agencies worldwide also operate schemes to support talented researchers and their institutions.

Yet good databases of the support available for capacity building and of promising talent do not exist. They would surely reveal opportunities for agencies and Northern labs to work better together to concentrate support on priority areas, and on the best science, to nurture enduring centres of excellence.

Furthermore, there is a case for one or more lightweight, international coordinating initiatives, including research organizations, donors and the private sector. Such initiatives could also set standards for peer review, and for ensuring that research funds don't end up in the hands of corrupt university or government officials - a problem rife in Africa. Agreements on competitive salaries are also urgently needed to stem the brain drain.

One immediate impact could be achieved cheaply by providing the best research centres in developing countries with high-speed satellite Internet access. Scientists in the few African laboratories that have it report not just greater access to information and better networking with colleagues, but vastly greater success in applying for overseas grants because they are more up to speed.

Putting science in developing countries on a stronger and more transparent footing would attract investment and raise the bar for the foreign ministries of Western governments who disburse large sums, but often on the basis of anything but good science. 